\title{
Synthesis and in vitro biological evaluation of new P2X7R radioligands [ $\left.{ }^{11} \mathrm{C}\right]$ halo-GSK1482160 analogs
}

\author{
Mingzhang Gao, Min Wang, Jill A. Meyer, Paul R. Territo, Gary D. Hutchins, Hamideh \\ Zarrinmayeh, Qi-Huang Zheng*
} Department of Radiology and Imaging Sciences, Indiana University School of Medicine, 1345 West $16^{\text {th }}$ Street, Room 202,
Indianapolis, IN 46202, USA

*Corresponding author. Tel.: +1 317-278-4671. Fax: +1 317-278-9711. E-mail address: qzheng@iupui.edu.

This is where the receipt/accepted dates will go; Received Month XX, 2019; Accepted Month XX, 2019 [BMCL RECEIPT]

\begin{abstract}
The reference standards halo-GSK1482160 (F-, Br-, and I-) and their corresponding precursors desmethyl-halo-GSK1482160 (F-, Br-, and I-) were synthesized from (S)-1-methyl-5-oxopyrrolidine-2-carboxylic acid or (S)-5-oxopyrrolidine-2-carboxylic acid and 2halo-3-(trifluoromethyl)benzylamine (F-, Br-, and I-) in one step with 45-93\% yields. The target tracers [ $\left.{ }^{11} \mathrm{C}\right]$ halo-GSK1482160 (F-, Br-, and I-) were prepared from desmethyl-halo-GSK1482160 (F-, Br-, and I-) with [ ${ }^{11} \mathrm{C}_{\mathrm{CH}_{3}} \mathrm{OTf}$ under basic conditions $\left(\mathrm{NaOH}^{-\mathrm{Na}} \mathrm{CO}_{3}\right.$, solid, w/w 1:2) through $N-\left[{ }^{11} \mathrm{C}\right]$ methylation and isolated by HPLC combined with SPE in 40-50\% decay corrected radiochemical yield. The radiochemical purity was $>99 \%$, and the molar activity $\left(\mathrm{A}_{\mathrm{M}}\right)$ at end of bombardment (EOB) was $370-740 \mathrm{GBq} / \mu \mathrm{mol}$. The potency of halo-GSK1482160 (F-, Br-, and I-) in comparison with GSK1482160 (Cl-) was determined by a radioligand competitive binding assay using $\left[{ }^{11} \mathrm{C}\right.$ ]GSK1482160, and the binding affinity $\mathrm{K}_{\mathrm{i}}$ values for halo-GSK1482160 (F-, Br-, and I-) and GSK1482160 (Cl-) are 54.2, 2.5, 1.9 and $3.1 \mathrm{nM}$, respectively.
\end{abstract}

Keywords: $\quad\left[{ }^{11} \mathrm{C}\right]$ Halo-GSK1482160 (F-, Br-, and I-); Purinergic P2X7 receptor (P2X7R); Radiosynthesis; Competitive binding assay; Positron emission tomography (PET).

The purinergic receptor $\mathrm{P} 2 \mathrm{X}$ ligand-gated ion channel type 7 (P2X7R) is an adenosine triphosphate (ATP)gated ion-channel, and $\mathrm{P} 2 \mathrm{X} 7 \mathrm{R}$ is a key player in inflammation. ${ }^{1} \mathrm{P} 2 \mathrm{X} 7 \mathrm{R}$ is an emerging therapeutic target in central nervous system (CNS) diseases such as Alzheimer's disease (AD) and Parkinson's disease (PD), because the overexpression of P2X7R is closely associated with neuroinflammation. ${ }^{2}$ P2X7R has become a novel molecular imaging target for neuroinflammation via biomedical imaging technique positron emission tomography (PET). ${ }^{3}$ Recently several radioligands targeting P2X7R have been developed and evaluated in animals and human, and the representative radioligands are shown in Figure 1. ${ }^{4-15}$ However, biological evaluation indicated some of these P2X7R radioligands have significant drawbacks like not potent enough binding affinity $\mathrm{K}_{\mathrm{i}}$ values, short half-life of radionuclide carbon-11 ( $\left.\mathrm{t}_{1 / 2}, 20.4 \mathrm{~min}\right)$, limited blood- brain barrier (BBB) penetration and/or little brain uptake. Thus an ideal $\mathrm{P} 2 \mathrm{X} 7 \mathrm{R}$ radioligand that can be used in the clinical setting to study P2X7R expression levels in neurodegenerative disorders remains to be discovered. In our previous work, we have developed and characterized $\left[{ }^{11} \mathrm{C}\right]$ GSK1482160 as a P2X7R radioligand for neuroinflammation, ${ }^{7,8}$ clinical evaluation of $\left[{ }^{11} \mathrm{C}\right] \mathrm{GSK} 1482160$ in healthy controls and patients is currently underway, the estimation of radiation dosimetry for $\left[{ }^{11} \mathrm{C}\right] \mathrm{GSK} 1482160$ in normal human subjects has been reported, and the results indicated brain uptake was low, but in most other organs the uptake and clearance of $\left[{ }^{11} \mathrm{C}\right] \mathrm{GSK} 1482160$ appears suitable for use in PET assessment of P2X7R expression as a potential marker of regional inflammation. ${ }^{15}$ In addition, a series of $\left[{ }^{18} \mathrm{~F}\right]$ fluoroalkyl derivatives of GSK1482160 like $\left[{ }^{18} \mathrm{~F}\right]$ fluoroethyl derivative $\quad\left[{ }^{18} \mathrm{~F}\right] \mathrm{IUR}-1601$ and $\quad\left[{ }^{18} \mathrm{~F}\right]$ fluoropropyl 
derivative $\left[{ }^{18} \mathrm{~F}\right] \mathrm{IUR}-1602$ have been also developed in this laboratory. ${ }^{12,13}$ Although these two fluorine-18 radioligands has a longer half-life $\left(\mathrm{t}_{1 / 2}, 109.7 \mathrm{~min}\right)$ and greater potential for widespread clinical use, they requires complicated two-step radiosynthetic procedures and are unstable under predisposing radiosynthetic conditions for an elimination reaction, resulting low radiochemical yield. ${ }^{12,13}$ To overcome the problems with $\left[{ }^{11} \mathrm{C}\right] \mathrm{GSK} 1482160$ (short half-life and low brain uptake) and with $\left[{ }^{18} \mathrm{~F}\right]$ IUR-1601 as well as $\left[{ }^{18} \mathrm{~F}\right] \mathrm{IUR}$ 1602 (complex radiosynthesis and short-term stability), in this ongoing study, we initially proposed to develop $\left[{ }^{18}\right.$ F]GSK1482160, in which GSK1482160 and its bromine and iodide analogs serve as the labeling precursors for $\left[{ }^{18} \mathrm{~F}\right] \mathrm{GSK} 1482160$, but the in vitro biological evaluation results of halo-GSK1482160 (F-, $\mathrm{Cl}-, \mathrm{Br}-$, and $\mathrm{I}-)$ analogs suggest $\left[{ }^{18} \mathrm{~F}\right] \mathrm{GSK} 1482160$ is not a useful radioligand, instead [ ${ }^{11} \mathrm{C}$ ]Br-GSK1482160 and $\left[{ }^{11} \mathrm{C}\right] \mathrm{I}-\mathrm{GSK} 1482160$ could be useful radioligands. Therefore, we turned our effort to develop $\left[{ }^{11} \mathrm{C}\right]$ haloGSK1482160 (F-, Br-, and I-) analogs. Herein, we report the design, synthesis, radiolabeling and initial in vitro biological evaluation of new $\mathrm{P} 2 \mathrm{X} 7 \mathrm{R}$ radioligands $\left[{ }^{11} \mathrm{C}\right]$ halo-GSK1482160 (F-, Br-, and I-) analogs (Figure 1).

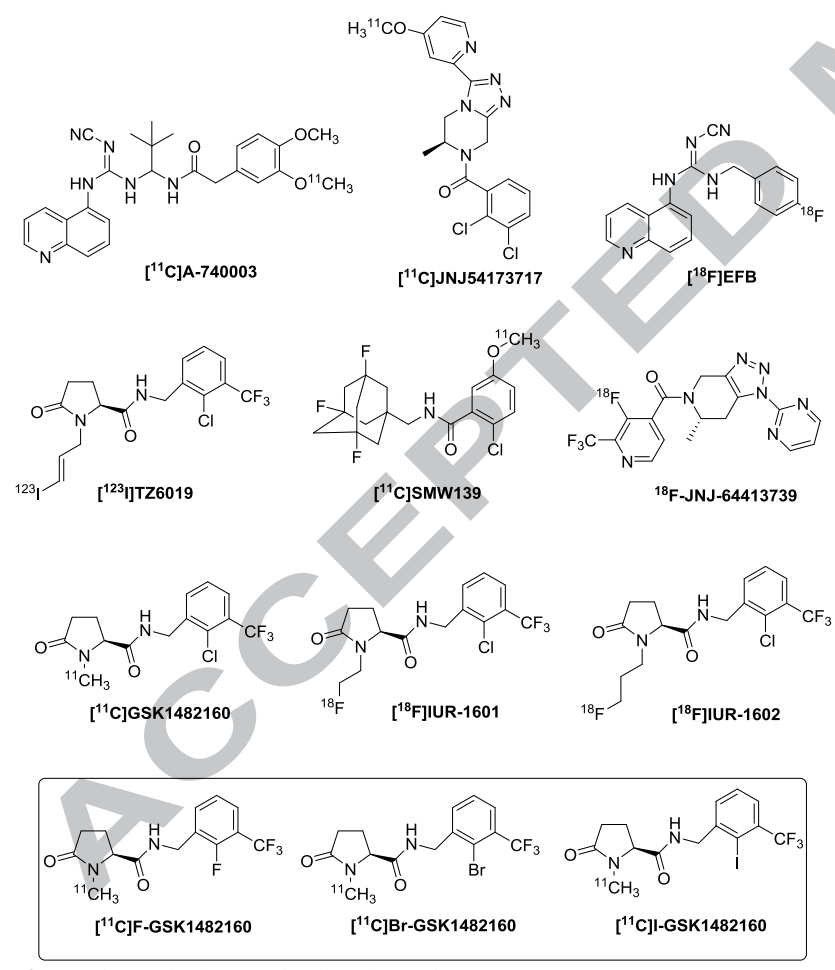

Figure 1. Radioligands for imaging of P2X7R.

The reference standards: F-GSK1482160 ((S)- $N-(3-$ fluoro-4-(trifluoromethyl)benzyl)-1-methyl-5oxopyrrolidine-2-carboxamide), Br-GSK1482160 ((S)$N$-(3-bromo-4-(trifluoromethyl)benzyl)-1-methyl-5oxopyrrolidine-2-carboxamide), I-GSK1482160 ((S)- $N$ (3-iodo-4-(trifluoromethyl)benzyl)-1-methyl-5- oxopyrrolidine-2-carboxamide); and their corresponding precursor: desmethyl-F-GSK1482160 ((S)- $N$-(3-fluoro4-(trifluoromethyl)benzyl)-5-oxopyrrolidine-2-

carboxamide), desmethyl-Br-GSK1482160 ((S)-N-(3bromo-4-(trifluoromethyl)benzyl)-5-oxopyrrolidine-2carboxamide), desmethyl-I-GSK1482160 ((S)- $N$-(3iodo-4-(trifluoromethyl)benzyl)-5-oxopyrrolidine-2carboxamide); were synthesized as outlined in Scheme 1, according to the published methods. ${ }^{7}$ The starting materials were either commercially available or synthesized in our previous work. ${ }^{7}$ (S)-1-Methyl-5oxopyrrolidine-2-carboxylic acid underwent a coupling reaction with 2-halo-3-(trifluoromethyl)benzylamine (F, Br-, and I-) using 2-ethoxy-1-ethoxycarbonyl-1,2dihydroquinoline (EEDQ) as a catalyst, affording haloGSK1482160 (F-, Br-, and I-). Likewise, $(S)-5$ oxopyrrolidine-2-carboxylic acid underwent a coupling reaction with 2-halo-3-(trifluoromethyl)benzylamine (F, Br-, and I-) using EEDQ as a catalyst, giving desmethyl-halo-GSK1482160 (F-, Br-, and I-). The yields of the coupling reaction were in the range of 4593\%. F-GSK1482160 appeared in the GlaxoSmithKline patents without biological activity data, ${ }^{16,17} \mathrm{Br}$ GSK1482160, I-GSK1482160, and all three desmethylated precursors are new compounds.

Synthesis of the target tracers $\left[{ }^{11} \mathrm{C}\right] \mathrm{F}-\mathrm{GSK} 1482160((S)$ $N$-(3-fluoro-4-(trifluoromethyl)benzyl)-1- $\left[{ }^{11} \mathrm{C}\right]$ methyl-

5-oxopyrrolidine-2-carboxamide), $\quad\left[{ }^{11} \mathrm{C}\right] \mathrm{Br}$ GSK1482160

((S)- $N$-(3-bromo-4(trifluoromethyl)benzyl)-1- $\left[{ }^{11} \mathrm{C}\right]$ methyl-5-

oxopyrrolidine-2-carboxamide), and $\quad\left[{ }^{11} \mathrm{C}\right] \mathrm{I}-$ GSK1482160

(trifluoromethyl)benzyl)-1- $\left[{ }^{11} \mathrm{C}\right]$ methyl-5-

oxopyrrolidine-2-carboxamide) is presented in Scheme 2. Desmethyl-halo-GSK1482160 (F-, Br-, and I-) underwent $N-\left[{ }^{11} \mathrm{C}\right]$ methylation ${ }^{7}$ using the reactive $\left[{ }^{11} \mathrm{C}\right]$ methylating agent $\left[{ }^{11} \mathrm{C}\right]$ methyl triflate $\left(\left[{ }^{11} \mathrm{C}\right] \mathrm{CH}_{3} \mathrm{OTf}\right)^{18,19}$ in acetonitrile at $80{ }^{\circ} \mathrm{C}$ under basic conditions (NaOH-Na $\mathrm{CO}_{3}$, solid, w/w 1:2). The product was isolated by semi-preparative reverse-phase (RP) high performance liquid chromatography (HPLC) with a C-18 column, and then concentrated by solidphase extraction (SPE) with a disposable C-18 Plus Sep-Pak cartridge to produce the corresponding pure radiolabeled compound $\left[{ }^{11} \mathrm{C}\right]$ halo-GSK1482160 (F-, Br, and I-) in 40-50\% radiochemical yield, decay corrected to end of bombardment (EOB), based on $\left[{ }^{11} \mathrm{C}\right] \mathrm{CO}_{2}$.

Desmethyl-halo-GSK1482160 (F-, Br-, and I-) contain both cyclic amide and side chain amide that can be $\mathrm{N}$ $\left[{ }^{11} \mathrm{C}\right]$ methylated. They are two competing reactions. Although the cyclic amide is more easily deprotonated and methylated than side chain amide to produce desired $\left[{ }^{11} \mathrm{C}\right]$ halo-GSK1482160 (F-, Br-, and I-), there 
was always a radiolabeled $\left[{ }^{11} \mathrm{C}\right]$ halo-GSK1482160 isomer ( $\mathrm{F}-, \mathrm{Br}-$, and $\mathrm{I}-)$ by-product $\left[{ }^{11} \mathrm{C}\right]$-methylated at side chain amide position formed. During the development, validation and production of $\left[{ }^{11}\right.$ C]GSK1482160, ${ }^{7}$ We surprisingly found out $\left[{ }^{11} \mathrm{C}\right] \mathrm{GSK} 1482160$ and its radiolabeled isomer were formed in different ratio using the old $\mathrm{NaH}$ base or freshly purchased $\mathrm{NaH}$ base. For old $\mathrm{NaH}$ used in development and optimization runs, $\left[{ }^{11}\right.$ C]GSK1482160 was formed as a major labeled product; but for freshly purchased $\mathrm{NaH}$ (expired in one year) used in validation and production runs, undesired $\left[{ }^{11} \mathrm{C}\right] \mathrm{GSK} 1482160$ isomer was formed as a major labeled product. The reason could be that old $\mathrm{NaH}$ might have absorbed moisture to become $\mathrm{NaOH}$ and/or reacted with $\mathrm{CO}_{2}$ in the air to become $\mathrm{NaHCO}_{3}$, a solid mixture of $\mathrm{NaOH}-$ $\mathrm{Na}_{2} \mathrm{CO}_{3}$. It is likely the different $\mathrm{pKa}$ value of cyclic amide and side chain amide requires different base for $N-\left[{ }^{11} \mathrm{C}\right]$ methylation. Consequently we investigated the base effect on the radiosynthesis of $\left[{ }^{11} \mathrm{C}\right]$ GSK 1482160 and its halo-analogs. The results are shown in Scheme 3. If $\mathrm{NaOH}-\mathrm{Na}_{2} \mathrm{CO}_{3}$ (w/w 1:2, solid) was used as a base, $\left[{ }^{11} \mathrm{C}\right]$ halo-GSK1482160 (F-, Br-, and I-) and $\left[{ }^{11} \mathrm{C}\right]$ haloGSK1482160 isomer (F-, Br-, and I-) were formed in a $\sim 10: 1$ ratio. If $\mathrm{NaOH}$ (solid) was used as a base, $\left[{ }^{11} \mathrm{C}\right]$ halo-GSK1482160 (F-, Br-, and I-) and $\left[{ }^{11} \mathrm{C}\right]$ haloGSK1482160 isomer (F-, Br-, and I-) were formed in a $\sim 1: 1$ ratio. If $\mathrm{NaH}(95 \%$ dry or $60 \%$ dispersion in mineral oil, powder) was used as a base, $\left[{ }^{11} \mathrm{C}\right]$ haloGSK1482160 (F-, Br-, and I-) and $\left[{ }^{11} \mathrm{C}\right]$ haloGSK1482160 isomer (F-, Br-, and I-) were formed in a $\sim 1: 10$ ratio.

The radiosynthesis was performed in a home-built automated multi-purpose $\quad\left[{ }^{11} \mathrm{C}\right]$-radiosynthesis module. ${ }^{20-22}$ Our radiosynthesis module facilitated the overall design of the reaction, purification and reformulation capabilities in a fashion suitable for adaptation to preparation of human doses. The radiosynthesis includes three stages: 1) labeling reaction; 2) purification; and 3) formulation. The overall synthesis time was $\sim 40$ min from EOB. Our module is also designed to allow in-process measurement of $\left[{ }^{11} \mathrm{C}\right]$ tracer molar activity $\left(\mathrm{A}_{\mathrm{M}}, \mathrm{GBq} / \mu \mathrm{mol}\right.$ at $\left.\mathrm{EOB}\right)$ using a radiation detector with a UV detector at the outlet of the HPLC-portion of the system. At the end of synthesis (EOS), the $\mathrm{A}_{\mathrm{M}}$ of $\left[{ }^{11} \mathrm{C}\right]$-tracer was determined again by analytical RP-HPLC, calculated, decay corrected to EOB, and based on $\left[{ }^{11} \mathrm{C}_{\mathrm{CO}_{2}}\right.$, which was in agreement with the 'on line' determined value. The $A_{M}$ of $\left[{ }^{11}\right.$ C] halo-GSK1482160 analogs at EOB was $370-740$ $\mathrm{GBq} / \mu \mathrm{mol}$.

Chemical purity and radiochemical purity were determined by analytical HPLC. ${ }^{23}$ The chemical purity of the precursor and reference standard was $>95 \%$ determined by RP-HPLC through UV flow detector. The radiochemical purity of the target tracer was $>99 \%$ determined by radio-HPLC through $\gamma$-ray (PIN diode) flow detector.
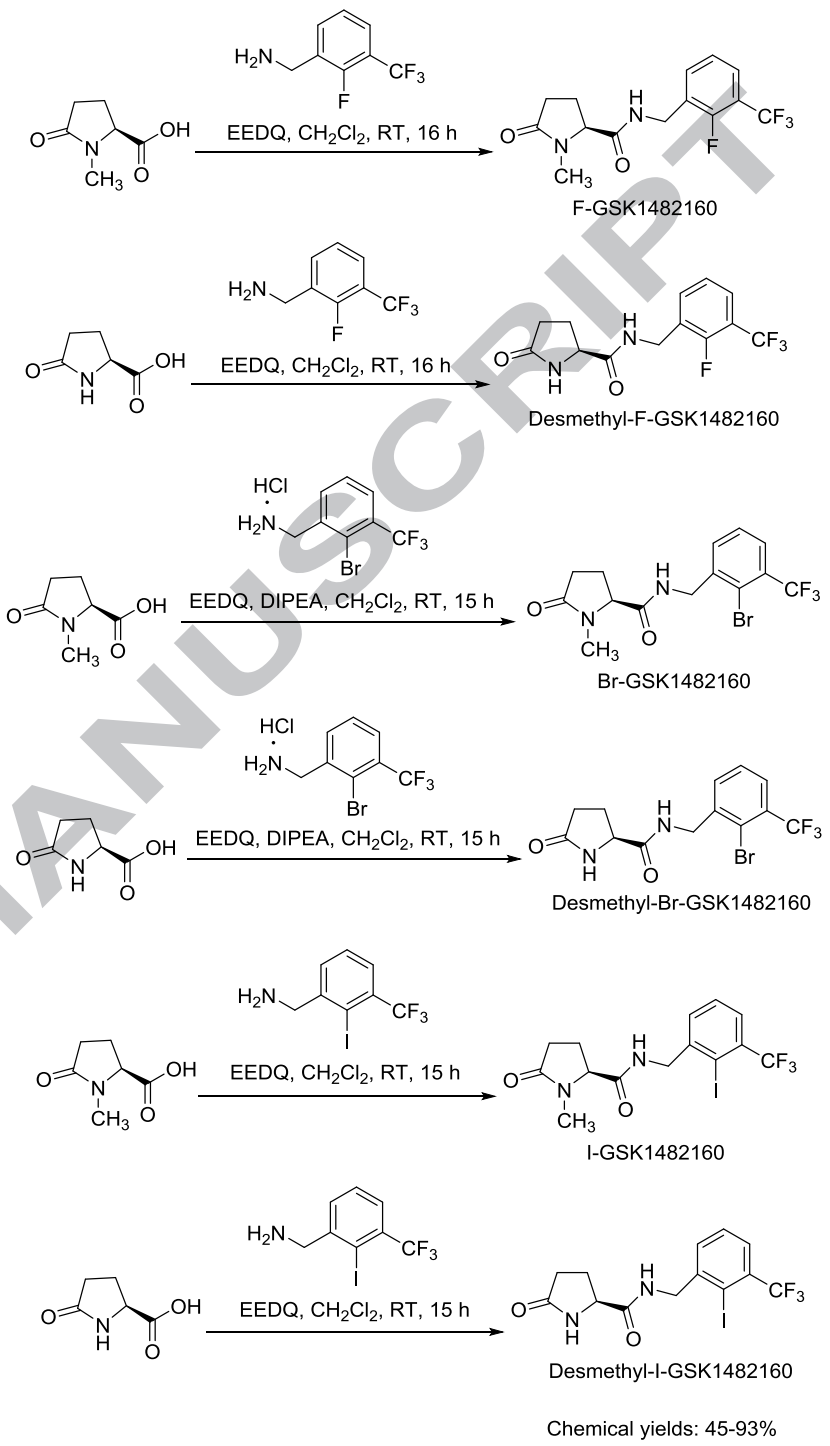

Scheme 1. Synthesis of the reference standards halo-GSK1482160 (F-, $\mathrm{Br}-$, and $\mathrm{I}-)$ and their corresponding precursor desmethyl-haloGSK1482160 (F-, Br-, and I-).

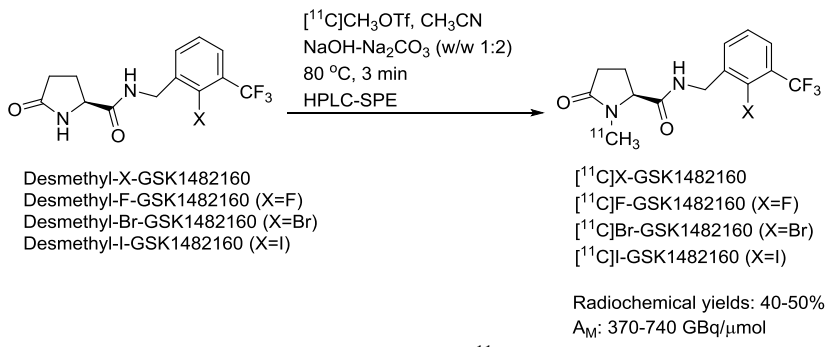

Scheme 2. Synthesis of the target tracers $\left[{ }^{11} \mathrm{C}\right]$ halo-GSK1482160 (F-, Br-, and $\mathrm{I}-$ ).

The preliminary biological evaluation of haloGSK1482160 (F-, Br-, and I-) in comparison with the known P2X7R ligand GSK1482160 was performed by a 
radioligand competitive binding assay using $\left.{ }_{24-26}^{11} \mathrm{C}\right]$ GSK 1482160 following the literature method. ${ }^{8,12,13}$, The results are shown in Figure 2. $\left[{ }^{11} \mathrm{C}\right] \mathrm{GSK} 1482160$ was used as the radioligand, GSK1482160 and buffer were used as a positive control and a negative control, respectively. All data were analyzed by GraphPad Prism 7.00 software using nonlinear regression and the competitive binding model One site - Fit $\mathrm{K}_{\mathrm{i}}$. The binding affinity $\mathrm{K}_{\mathrm{i}}$ values for GSK1482160 (F-, Br-, and I-) and GSK1482160 are $54.2 \pm 6.2 \mathrm{nM}, 2.5 \pm 0.7 \mathrm{nM}, 1.9 \pm 0.6 \mathrm{nM}$, and $3.1 \pm$ $0.3 \mathrm{nM}(\mathrm{n}=3)$, respectively. The $\mathrm{IC}_{50}$ values for GSK1482160 (F-, Br-, and I-) and GSK1482160 are $152.6 \pm 17.5 \mathrm{nM}, 7.1 \pm 1.9 \mathrm{nM}, 5.3 \pm 1.5 \mathrm{nM}$, and $8.9 \pm$ $1.0 \mathrm{nM}(\mathrm{n}=3)$, respectively, also obtained via GraphPad Prism 7.00 software using nonlinear regression and the competitive binding model One site - Fit $\log \mathrm{IC}_{50}$.

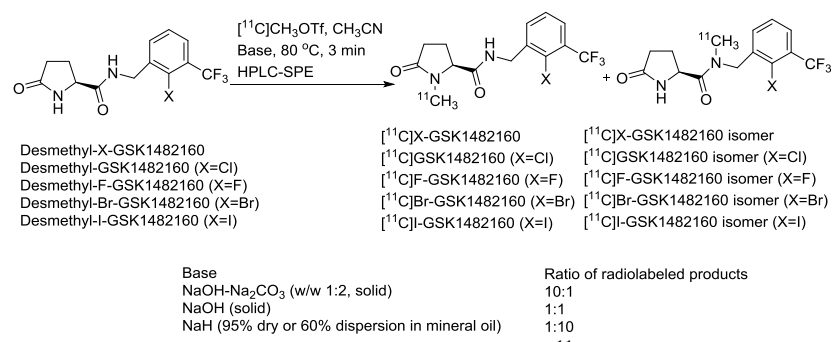

Scheme 3. Base effect on the radiosynthesis of $\left[{ }^{11} \mathrm{C}\right] \mathrm{GSK} 1482160$ and its halo-analogs.

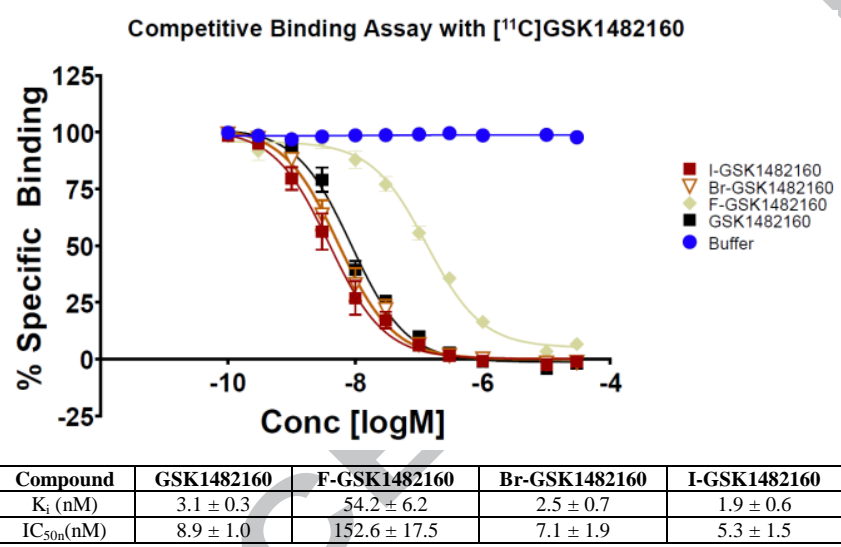

Figure 2. The result of the competitive binding assay of haloGSK1482160 (F-, Br-, and I-) in comparison with GSK1482160.

The experimental details and characterization data for halo-GSK1482160 (F-, Br-, and I-), desmethyl-haloGSK1482160 (F-, Br-, and I- $)$ and $\left[{ }^{11} \mathrm{C}\right]$ haloGSK1482160 (F-, Br-, and I-), as well as radioligand competitive binding assay are given. ${ }^{27}$

In summary, facile synthetic routes with moderate to excellent yields have been developed to produce the precursors desmethyl-halo-GSK1482160 (F-, Br-, and I), the reference standards halo-GSK1482160 (F-, Br-, and $\mathrm{I}-)$, and the target PET radiotracers $\left[{ }^{11} \mathrm{C}\right]$ haloGSK1482160 (F-, Br-, and I-). The radiosynthesis employed $\left[{ }^{11} \mathrm{C}\right] \mathrm{CH}_{3} \mathrm{OTf}$ for $N$ - $\left[{ }^{11} \mathrm{C}\right]$ methylation at the nitrogen position of the amide precursors, followed by product purification and isolation by a semi-preparative RP-HPLC combined with SPE. The base effect on the radiotracer production of $\left[{ }^{11} \mathrm{C}\right] \mathrm{GSK} 1482160$ and $\left[{ }^{11} \mathrm{C}\right]$ halo-GSK1482160 (F-, Br-, and I-) has been investigated. The desired $\left[{ }^{11} \mathrm{C}\right]$ halo-GSK1482160 (F-, $\mathrm{Br}-$, and I-) were obtained in high radiochemical yield, and radiochemical purity, with a reasonably short overall synthesis time, and high molar activity. New P2X7R radioligands $\left[{ }^{11}\right.$ C]halo-GSK1482160 (F-, Br-, and I-) have been successfully radiosynthesized. The initial in vitro biological evaluation results indicate that $\left[{ }^{11} \mathrm{C}\right]$ F-GSK1482160 has $\sim 17$-fold less potency compared to the parent radioligand $\left[{ }^{11} \mathrm{C}\right] \mathrm{GSK} 1482160$, but remains low $\mathrm{nM}$ grade $\mathrm{P} 2 \mathrm{X} 7 \mathrm{R}$ affinity; $\left[{ }^{11} \mathrm{C}\right] \mathrm{Br}$ GSK1482160 and $\left[{ }^{11} \mathrm{C}\right] \mathrm{I}-\mathrm{GSK} 1482160$ display very similar even superior P2X7R affinity to $\left[{ }^{11} \mathrm{C}\right]$ GSK1482160. These will facilitate studies to evaluate $\left[{ }^{11} \mathrm{C}\right] \mathrm{Br}-\mathrm{GSK} 1482160$ and $\left[{ }^{11} \mathrm{C}\right] \mathrm{I}-\mathrm{GSK} 1482160$ as new PET radiopharmaceuticals for targeting the $\mathrm{P} 2 \mathrm{X}_{7}$ receptor in animals and humans. The in vivo biological evaluation of $\left[{ }^{11} \mathrm{C}\right] \mathrm{Br}-\mathrm{GSK} 1482160$ and $\left[{ }^{11} \mathrm{C}\right] \mathrm{I}-$ GSK1482160 is currently underway.

\section{Acknowledgments}

This work was partially supported by Indiana University Showalter Young Investigator Award and Indiana University Department of Radiology and Imaging Sciences in the United States. ${ }^{1} \mathrm{H}$ NMR and ${ }^{13} \mathrm{C}$ NMR spectra were recorded at 500 and $125 \mathrm{MHz}$, respectively, on a Bruker Avance II $500 \mathrm{MHz}$ NMR spectrometer in the Department of Chemistry and Chemical Biology at Indiana University Purdue University Indianapolis (IUPUI), which is supported by the United States National Science Foundation (NSF) Major Research Instrumentation Program (MRI) grant CHE-0619254.

\section{References and notes}

1. Lister MF, Sharkey J, Sawatzky DA, Hodgkiss JP, Davidson DJ, Rossi AG, Finlayson K. The role of the purinergic $\mathrm{P} 2 \mathrm{X}_{7}$ receptor in inflammation. J Inflamm (Lond). 2007;4:5.

2. Sperlágh B, Illes P. P2X7 receptor: an emerging target in central nervous system diseases. Trends Pharmacol Sci. 2014;35:537-547.

3. Tronel C, Largeau B, Santiago Ribeiro MJ, Guilloteau D, Dupont AC, Arlicot N. Molecular targets for PET imaging of activated microglia: The current situation and future expectations. Int J Mol Sci. 2017;18:E802.

4. Janssen B, Vugts DJ, Funke U, Spaans A, Schuit RC, Kooijman E, Rongen M, Perk LR, Lammertsma AA, Windhorst AD. Synthesis and initial preclinical evaluation of the $\mathrm{P} 2 \mathrm{X} 7$ receptor antagonist $\left[{ }^{11} \mathrm{C}\right] \mathrm{A}$ - 
740003 as a novel tracer of neuroinflammation. J Labelled Comp Radiopharm. 2014;57:509-516.

5. Ory D, Celen S, Gijsbers R, Van Den Haute C, Postnov A, Koole M, Vandeputte C, Andrés JI, Alcazar J, De Angelis M, Langlois X, Bhattacharya A, Schmidt M, Letavic MA, Vanduffel W, Van Laere K, Verbruggen A, Debyser Z, Bormans G. Preclinical evaluation of a $\mathrm{P} 2 \mathrm{X} 7$ receptor-selective radiotracer: PET studies in a rat model with local overexpression of the human P2X7 receptor and in nonhuman primates. J Nucl Med. 2016;57:1436-1441.

6. Fantoni ER, Dal Ben D, Falzoni S, Di Virgilio F, Lovestone S, Gee A. Design, synthesis and evaluation in an LPS rodent model of neuroinflammation of a novel ${ }^{18}$ F-labelled PET tracer targeting P2X7. EJNMMI Res. 2017;7:31.

7. Gao M, Wang M, Green MA, Hutchins GD, Zheng Q.-H. Synthesis of $\left[{ }^{11} \mathrm{C}\right]$ GSK1482160 as a new PET agent for targeting P2 $\mathrm{X}_{7}$ receptor. Bioorg Med Chem Lett. 2015;25:1965-1970.

8. Territo PR, Meyer JA, Peters JS, Riley AA, McCarthy BP, Gao M, Wang M, Green MA, Zheng Q.-H, Hutchins GD. Characterization of ${ }^{11}$ C-GSK1482160 for targeting the $\mathrm{P} 2 \mathrm{X} 7$ receptor as a biomarker for neuroinflammation. J Nucl Med. 2017;58:458-465.

9. Han J, Liu H, Liu C, Jin H, Perlmutter JS, Egan TM, $\mathrm{Tu}$ Z. Pharmacologic characterizations of a P2X7 receptor-specific radioligand, $\left[{ }^{11} \mathrm{C}\right] \mathrm{GSK} 1482160$ for neuroinflammatory response. Nucl Med Commun. 2017;38:372-382.

10. Jin H, Han J, Resing D, Liu H, Yue X, Miller RL, Schoch KM, Miller TM, Perlmutter JS, Egan TM, Tu Z. Synthesis and in vitro characterization of a P2X7 radioligand $\left[{ }^{123} \mathrm{I}\right] \mathrm{TZ6019}$ and its response to neuroinflammation in a mouse model of Alzheimer disease. Eur J Pharmacol. 2018;820:8-17.

11. Janssen B, Vugts DJ, Wilkinson SM, Ory D, Chalon S, Hoozemans JJM, Schuit RC, Beaino W, Kooijman EJM, van den Hoek J, Chishty M, Doméné A, Van der Perren A, Villa A, Maggi A, Molenaar GT, Funke U, Shevchenko RV, Baekelandt V, Bormans G, Lammertsma AA, Kassiou M, Windhorst AD. Identification of the allosteric $\mathrm{P}_{2} \mathrm{X}_{7}$ receptor antagonist $\left[{ }^{11} \mathrm{C}\right] \mathrm{SMW} 139$ as a PET tracer of microglial activation. Sci Rep. 2018;8:6580.

12. Gao M, Wang M, Glick-Wilson BE, Meyer JA, Peters JS, Territo PR, Green MA, Hutchins GD, Zarrinmayeh H, Zheng Q.-H. Synthesis and preliminary biological evaluation of a novel P2X7R radioligand $\left[{ }^{18} \mathrm{~F}\right] \mathrm{IUR}$ 1601. Bioorg Med Chem Lett. 2018;28:1603-1609.

13. Gao M, Wang M, Glick-Wilson BE, Meyer JA, Peters JS, Territo PR, Green MA, Hutchins GD, Zarrinmayeh $\mathrm{H}$, Zheng Q.-H. Synthesis and initial in vitro characterization of a new P2X7R radioligand $\left[{ }^{18}\right.$ F]IUR-1602. Appl Radiat Isot. 2019;144:10-18.

14. Koole M, Schmidt M, Hijzen A, Ravenstijn P, Vandermeulen C, Van Weehaeghe D, Serdons K, Celen S, Bormans G, Ceusters M, Zhang W, Van Nueten L, Kolb H, de Hoon J, Van Laere K. ${ }^{18}$ F-JNJ-
64413739, a novel PET ligand for the P2X7 ion channel: radiation dosimetry, kinetic modeling, testretest variability and occupancy of the $\mathrm{P} 2 \mathrm{X} 7$ antagonist JNJ-54175446. J Nucl Med. 2018 Sep 27. pii: jnumed.118.216747. doi: 10.2967/jnumed.118.216747. [Epub ahead of print]

15. Green MA, Hutchins GD, Fletcher JW, Territo W, Polson H, Trussell HK, Wissmann CL, Zheng Q.-H, Gao M, Wang M, Glick-Wilson BE. Distribution of the P2X7-receptor-targeted $\quad\left[{ }^{11}\right.$ C]GSK1482160 radiopharmaceutical in normal human subjects. J Nucl Med. 2018;59(S1):1009.

16. Michel AD, Walter DS. Preparations of prolinamide p2 77 modulators and their combinations with other therapeutic agents. WO 2009074518A1 20090618.

17. Chambers LJ, Gleave R, Senger S, Walter DS. Preparation of $N$-(phenylmethyl)-5-oxoprolinamides derivatives as $\mathrm{P} 2 \mathrm{X} 7$ antagonists for the treatment of pain, inflammation and neurodegeneration. WO 2008003697A1 20080110.

18. Jewett DM. A simple synthesis of $\left[{ }^{11} \mathrm{C}\right]$ methyl triflate. Int J Rad Appl Instrum A. 1992;43:1383-1385.

19. Mock BH, Mulholland GK, Vavrek MT. Convenient gas phase bromination of $\left[{ }^{11} \mathrm{C}\right]$ methane and production of $\left[{ }^{11} \mathrm{C}\right]$ methyl triflate. Nucl Med Biol. 1999;26:467471.

20. Wang M, Gao M, Zheng Q.-H. Fully automated synthesis of PET TSPO radioligands $\left[{ }^{11}\right.$ C]DAA1106 and $\left[{ }^{18}\right.$ F]FEDAA1106. Appl Radiat Isot. 2012;70:965973.

21. Mock BH, Zheng Q.-H, DeGrado TR. A multipurpose ${ }^{11} \mathrm{C}$-radio-synthesis system. J Labelled Compd Radiopharm. 2005;48:S225.

22. Mock BH, Glick-Wilson BE, Zheng Q.-H, DeGrado TR. Automated measurement of specific activity of radiolabeled ligands during synthesis. J Labelled Compd Radiopharm. 2005;48:S224.

23. Zheng Q.-H, Mock BH. Purification of carbon-11 PET radiotracers from unlabeled precursors by preparative HPLC and SPE. Biomed Chromatogr. 2005;19:671676.

24. Gao M, Wang M, Meyer JA, Peters JS, Zarrinmayeh H, Territo PR, Hutchins GD, Zheng Q.-H. Synthesis and preliminary biological evaluation of $\left[{ }^{11} \mathrm{C}\right]$ methyl (2-amino-5-(benzylthio)thiazolo[4,5- $d]$ pyrimidin-7-

yl)-d-leucinate for the fractalkine receptor (CX3CR1). Bioorg Med Chem Lett. 2017;27:2727-2730.

25. Wang M, Gao M, Meyer JA, Peters JS, Zarrinmayeh H, Territo PR, Hutchins GD, Zheng Q.-H. Synthesis and preliminary biological evaluation of radiolabeled 5-BDBD analogs as new candidate PET radioligands for P2X4 receptor. Bioorg Med Chem. 2017;25:38353844.

26. Sihver W, Sihver S, Bergström M, Murata $T$, Matsumura K, Onoe H, Andersson Y, Bjurling P, Fasth KJ, Westerberg G, Ogren M, Jacobsson G, Lundqvist H, Oreland L, Watanabe Y, Långström B. Methodological aspects for in vitro characterization of receptor binding using ${ }^{11} \mathrm{C}$-labeled receptor ligands: a 
detailed study with the benzodiazepine receptor antagonist $\left[{ }^{11} \mathrm{C}\right] \mathrm{Ro}$ 15-1788. Nucl Med Biol. 1997;24:723-731.

27. (a). General: All commercial reagents and solvents were purchased from Sigma-Aldrich and Fisher Scientific, and used without further purification. Melting points were determined on a MEL-TEMP II capillary tube apparatus and were uncorrected. ${ }^{1} \mathrm{H}$ and ${ }^{13} \mathrm{C}$ NMR spectra were recorded on a Bruker Avance II $500 \mathrm{MHz}$ NMR Fourier transform spectrometer at 500 and $125 \mathrm{MHz}$, respectively. Chemical shifts $(\delta)$ are reported in parts per million (ppm) relative to an internal standard tetramethylsilane (TMS, $\delta 0.0)\left({ }^{1} \mathrm{H}\right.$ $\mathrm{NMR})$ and to the solvent signal $\left({ }^{13} \mathrm{C} \mathrm{NMR}\right)$, and coupling constants $(J)$ are reported in hertz $(\mathrm{Hz})$. Liquid chromatography-mass spectra (LC-MS) analysis was performed on an Agilent system, consisting of an 1100 series HPLC connected to a diode array detector and a 1946D mass spectrometer configured for positive-ion/negative-ion electrospray ionization. The high resolution mass spectra (HRMS) were obtained using a Waters/Micromass LCT Classic spectrometer. Chromatographic solvent proportions are indicated as volume: volume ratio. Thin-layer chromatography (TLC) was run using Analtech silica gel GF uniplates $\left(5 \times 10 \mathrm{~cm}^{2}\right)$. Plates were visualized under UV light. Normal phase flash column chromatography was carried out on EM Science silica gel 60 (230-400 mesh) with a forced flow of the indicated solvent system in the proportions described below. All moisture- and air-sensitive reactions were performed under a positive pressure of nitrogen maintained by a direct line from a nitrogen source. C18 Plus Sep-Pak cartridges were obtained from Waters Corporation (Milford, MA). Sterile Millex-FG $0.2 \mu \mathrm{m}$ filter units were obtained from Millipore Corporation (Bedford, MA). $\left[{ }^{11} \mathrm{C}\right] \mathrm{GSK} 1482160$ is a routine radiotracer produced in our PET radiochemistry facility. The analytical RP-HPLC system included a Prodigy (Phenomenex) $5 \mu \mathrm{m} \mathrm{C}-18$ column, $4.6 \times 250 \mathrm{~mm}$, mobile phase $35 \%$ $\mathrm{CH}_{3} \mathrm{CN} / 65 \% 20 \mathrm{mM} \mathrm{H} \mathrm{PO}_{4}$, flow rate $1.8 \mathrm{~mL} / \mathrm{min}$; UV $(275 \mathrm{~nm})$ and $\gamma$-ray (PIN diode) flow detectors. The semi-preparative RP-HPLC system included a Prodigy (Phenomenex) $5 \mu \mathrm{m}$ C- 18 column, $10 \times 250$ $\mathrm{mm}$, mobile phase $35 \% \quad \mathrm{CH}_{3} \mathrm{CN} / 65 \% \quad 0.1 \quad \mathrm{M}$ $\mathrm{CH}_{3} \mathrm{CO}_{2} \mathrm{Na}$, flow rate 6,7 , and $8 \mathrm{~mL} / \mathrm{min}$ for $\left[{ }^{11} \mathrm{C}\right] \mathrm{F}-$ GSK1482160, $\left[{ }^{11} \mathrm{C}\right]$ Br-GSK1482160, and $\left[{ }^{11} \mathrm{C}\right] \mathrm{I}-$ GSK1482160, respectively; UV (254 nm) and $\gamma$-ray (PIN diode) flow detectors.

(b). General synthetic method for F-GSK1482160 ((S)-N-(3-fluoro-4-(trifluoromethyl)benzyl)-1-methyl5-oxopyrrolidine-2-carboxamide), Br-GSK1482160 ((S)-N-(3-bromo-4-(trifluoromethyl)benzyl)-1-methyl5-oxopyrrolidine-2-carboxamide), I-GSK1482160 ((S)-N-(3-iodo-4-(trifluoromethyl)benzyl)-1-methyl-5oxopyrrolidine-2-carboxamide); desmethyl-FGSK1482160 ((S)- $N$-(3-fluoro-4- (trifluoromethyl)benzyl)-5-oxopyrrolidine-2carboxamide), desmethyl-Br-GSK1482160 ((S)-N-(3bromo-4-(trifluoromethyl)benzyl)-5-oxopyrrolidine-2carboxamide), desmethyl-I-GSK1482160 ((S)- N-(3iodo-4-(trifluoromethyl)benzyl)-5-oxopyrrolidine-2-

carboxamide): (S)-1-Methyl-5-oxopyrrolidine-2carboxylic acid or (S)-5-oxopyrrolidine-2-carboxylic acid $(2.0 \mathrm{mmol})$ was suspended in $\mathrm{CH}_{2} \mathrm{Cl}_{2}(60 \mathrm{~mL})$, and EEDQ $(2.2 \mathrm{mmol})$ was added. The mixture was stirred at room temperature (RT) for $10 \mathrm{~min}$. A solution of 2-fluoro-3-(trifluoromethyl)benzylamine (2.1 mmol), 2-bromo-3-(trifluoromethyl)benzylamine $\mathrm{HCl}$ salt $(2.1 \mathrm{mmol})$ with $\mathrm{N}, \mathrm{N}$-Diisopropylethylamine (DIPEA, $\quad 3.0 \mathrm{mmol}$ ), or 2-iodo-3(trifluoromethyl)benzylamine $(2.1 \mathrm{mmol})$ in $\mathrm{CH}_{2} \mathrm{Cl}_{2}$ $(20 \mathrm{~mL})$ was then added dropwise to the mixture. The mixture was then stirred at RT for 15-16 h. The reaction was monitored by TLC. The mixture was washed with saturated aqueous $\mathrm{NaHCO}_{3}(40 \mathrm{~mL}), 2 \mathrm{~N}$ aqueous $\mathrm{HCl}(40 \mathrm{~mL} \times 2)$, and water. The organic solution was dried over $\mathrm{Na}_{2} \mathrm{SO}_{4}$, filtered and concentrated in vacuo. The resulting crude product was then purified by column chromatography on silica gel with eluent (3-7\% $\mathrm{MeOH} / \mathrm{CH}_{2} \mathrm{Cl}_{2}$ ) to obtain white solid product (45-93\%). F-GSK1482160: Mp 111-112 ${ }^{\circ} \mathrm{C} .{ }^{1} \mathrm{H}$ NMR (acetone- $\left.\mathrm{d}_{6}\right): \delta 1.99-2.04(\mathrm{~m}, 1 \mathrm{H}, \mathrm{CH})$, 2.30-2.36 (m, 1H, CH), 2.37-2.47 (m, $\left.2 \mathrm{H}, \mathrm{CH}_{2}\right), 2.78$ $\left(\mathrm{s}, 3 \mathrm{H}, \mathrm{NCH}_{3}\right), 4.01(\mathrm{dd}, J=4.0,4.9 \mathrm{~Hz}, 1 \mathrm{H}, \mathrm{CH})$, $4.56\left(\mathrm{~d}, J=5.9 \mathrm{~Hz}, 2 \mathrm{H}, \mathrm{CH}_{2}\right), 6.82($ br s, $1 \mathrm{H}, \mathrm{NH})$, 7.21 (t, $J=7.7 \mathrm{~Hz}, 1 \mathrm{H}, \mathrm{Ph}-\mathrm{H}), 7.57$ (d, $J=7.6 \mathrm{~Hz}, 2 \mathrm{H}$, $\mathrm{Ph}-\mathrm{H})$. MS (ESI): $319 \quad\left([\mathrm{M}+\mathrm{H}]^{+}, \quad 100 \%\right)$. BrGSK1482160: $\mathrm{Mp} 168-169{ }^{\circ} \mathrm{C} .{ }^{1} \mathrm{H}$ NMR $\left(\mathrm{CDCl}_{3}\right): \delta$ 2.03-2.05 (m, 1H, CH), 2.27-2.32 (m, 1H, CH), 2.36$2.39(\mathrm{~m}, 1 \mathrm{H}, \mathrm{CH}), 2.42-2.47(\mathrm{~m}, 1 \mathrm{H}, \mathrm{CH}), 2.80(\mathrm{~s}, 3 \mathrm{H}$, $\left.\mathrm{NCH}_{3}\right), 4.00(\mathrm{dd}, J=4.0,4.5 \mathrm{~Hz}, 1 \mathrm{H}, \mathrm{CH}), 4.62-4.66$ (m, 2H, $\mathrm{CH}_{2}$ ), 6.88 (br s, 1H, NH), 7.41 (t, $J=5.5 \mathrm{~Hz}$, 1H, Ph-H), 7.57 (d, $J=6.0 \mathrm{~Hz}, 1 \mathrm{H}, \mathrm{Ph}-\mathrm{H}), 7.64$ (d, $J=$ $6.5 \mathrm{~Hz}, 1 \mathrm{H}, \mathrm{Ph}-\mathrm{H}) .{ }^{13} \mathrm{C}$ NMR $\left(\mathrm{CDCl}_{3}\right): \delta 23.42,29.22$, $29.42,44.44,63.81,121.51,122.81\left(\mathrm{q}, J_{\mathrm{C}-\mathrm{F}}=271.9\right.$ $\left.\mathrm{Hz}, \mathrm{CF}_{3}\right), 127.48\left(\mathrm{q}, J_{\mathrm{C}-\mathrm{F}}=5.4 \mathrm{~Hz}\right), 127.61,131.21(\mathrm{~d}$, $\left.J_{\mathrm{C}-\mathrm{F}}=30.6 \mathrm{~Hz}\right), 133.86,139.52,171.50,175.94$. HRMS (ESI): calcd for $\mathrm{C}_{14} \mathrm{H}_{15} \mathrm{~N}_{2} \mathrm{O}_{2} \mathrm{BrF}_{3}\left([\mathrm{M}+\mathrm{H}]^{+}\right)$ 379.0264, found 379.0267. I-GSK1482160: Mp 175$176{ }^{\circ} \mathrm{C} .{ }^{1} \mathrm{H}$ NMR $\left(\mathrm{CDCl}_{3}\right): \delta 2.02-2.07(\mathrm{~m}, 1 \mathrm{H}, \mathrm{CH})$, 2.30-2.41 (m, 2H, $\left.\mathrm{CH}_{2}\right), 2.43-2.51(\mathrm{~m}, 1 \mathrm{H}, \mathrm{CH}), 2.83$ (s, $\left.3 \mathrm{H}, \mathrm{NCH}_{3}\right), 4.01(\mathrm{dd}, J=3.5,5.0 \mathrm{~Hz}, 1 \mathrm{H}, \mathrm{CH})$, 4.61-4.64 (m, 2H, $\left.\mathrm{CH}_{2}\right), 6.97$ (br s, $\left.1 \mathrm{H}, \mathrm{NH}\right), 7.44$ (t, $J$ $=5.0 \mathrm{~Hz}, 1 \mathrm{H}, \mathrm{Ph}-\mathrm{H}), 7.55(\mathrm{~d}, J=7.5 \mathrm{~Hz}, 1 \mathrm{H}, \mathrm{Ph}-\mathrm{H})$, $7.61(\mathrm{~d}, J=7.5 \mathrm{~Hz}, 1 \mathrm{H}, \mathrm{Ph}-\mathrm{H}) .{ }^{13} \mathrm{C}$ NMR $\left(\mathrm{CDCl}_{3}\right): \delta$ 23.41, 29.30, 29.44, 49.56, 63.80, 96.63, $122.92\left(\mathrm{q}, J_{\mathrm{C}-}\right.$ $\left.\mathrm{F}=272.4 \mathrm{~Hz}, \mathrm{CF}_{3}\right), 127.22\left(\mathrm{q}, J_{\mathrm{C}-\mathrm{F}}=5.9 \mathrm{~Hz}\right), 128.49$, $132.98,134.89\left(\mathrm{~d}, J_{\mathrm{C}-\mathrm{F}}=30.5 \mathrm{~Hz}\right), 142.95,171.40$, 175.87. HRMS (ESI): calcd for $\mathrm{C}_{14} \mathrm{H}_{15} \mathrm{~N}_{2} \mathrm{O}_{2} \mathrm{IF}_{3}$ $\left([\mathrm{M}+\mathrm{H}]^{+}\right)$427.0125, found 427.0125. Desmethyl-FGSK1482160: $\mathrm{Mp} \mathrm{109-110}{ }^{\circ} \mathrm{C} .{ }^{1} \mathrm{H}$ NMR (acetone- $\mathrm{d}_{6}$ ): $\delta$ 2.12-2.17 (m, $1 \mathrm{H}, \mathrm{CH}), 2.22-2.34\left(\mathrm{~m}, 2 \mathrm{H}, \mathrm{CH}_{2}\right)$, $2.45-2.53(\mathrm{~m}, 1 \mathrm{H}, \mathrm{CH}), 4.19(\mathrm{dd}, J=4.5,5.9 \mathrm{~Hz}, 1 \mathrm{H}$, $\mathrm{CH}), 4.47-4.56\left(\mathrm{~m}, 2 \mathrm{H}, \mathrm{CH}_{2}\right), 7.19$ (br s, $\left.1 \mathrm{H}, \mathrm{NH}\right)$, 
$7.21(\mathrm{dd}, J=3.8,5.6 \mathrm{~Hz}, 2 \mathrm{H}, \mathrm{Ph}-\mathrm{H}), 7.51$ (t, $J=6.9$ $\mathrm{Hz}, 1 \mathrm{H}, \mathrm{Ph}-\mathrm{H}), 7.56$ (br s, $1 \mathrm{H}, \mathrm{NH}) .{ }^{13} \mathrm{C}$ NMR $\left(\mathrm{CDCl}_{3}\right): \delta$ 25.66, 29.22, 36.95, 57.14, $118.40\left(\mathrm{dd}, J_{\mathrm{C}-}\right.$ $\mathrm{F}=12.5,32.5 \mathrm{~Hz}), 122.52\left(\mathrm{q}, J_{\mathrm{C}-\mathrm{F}}=271.2 \mathrm{~Hz}, \mathrm{CF}_{3}\right)$, $124.13\left(\mathrm{~d}, J_{\mathrm{C}-\mathrm{F}}=5.0 \mathrm{~Hz}\right), 126.45\left(\mathrm{~d}, J_{\mathrm{C}-\mathrm{F}}=5.0 \mathrm{~Hz}\right)$, $126.76\left(\mathrm{~d}, J_{\mathrm{C}-\mathrm{F}}=137.5 \mathrm{~Hz}\right), 134.21\left(\mathrm{~d}, J_{\mathrm{C}-\mathrm{F}}=3.7 \mathrm{~Hz}\right)$, $157.84\left(\mathrm{~d}, J_{\mathrm{C}-\mathrm{F}}=2.5 \mathrm{~Hz}\right), 172.66,179.75$. HRMS (ESI): calcd for $\mathrm{C}_{13} \mathrm{H}_{13} \mathrm{~N}_{2} \mathrm{O}_{2} \mathrm{~F}_{4}\left([\mathrm{M}+\mathrm{H}]^{+}\right)$305.0908, found 305.0911. Desmethyl-Br-GSK1482160: Mp 190-191 ${ }^{\circ} \mathrm{C} .{ }^{1} \mathrm{H}$ NMR $\left(\mathrm{CDCl}_{3}\right): \delta 2.02-2.05(\mathrm{~m}, 1 \mathrm{H}$, $\mathrm{CH}), 2.28-2.32(\mathrm{~m}, 1 \mathrm{H}, \mathrm{CH}), 2.36-2.40(\mathrm{~m}, 1 \mathrm{H}, \mathrm{CH})$, 2.42-2.47 (m, 1H, CH), 4.01 (dd, $J=4.0,4.5 \mathrm{~Hz}, 1 \mathrm{H}$, $\mathrm{CH})$, 4.53-4.63 (m, 2H, $\left.\mathrm{CH}_{2}\right), 6.88$ (br s, 1H, NH), 7.41 (dd, $J=5.5,7.0 \mathrm{~Hz}, 1 \mathrm{H}, \mathrm{Ph}-\mathrm{H}), 7.57$ (d, $J=6.0$ $\mathrm{Hz}, 1 \mathrm{H}, \mathrm{Ph}-\mathrm{H}), 7.64$ (d, $J=6.5 \mathrm{~Hz}, 1 \mathrm{H}, \mathrm{Ph}-\mathrm{H}), 7.69$ (br s, $1 \mathrm{H}, \mathrm{NH}) .{ }^{13} \mathrm{C} \mathrm{NMR}\left(\mathrm{CDCl}_{3}+\mathrm{CD}_{3} \mathrm{OD}\right): \delta 25.49$, $29.24,43.95,56.85,121.10,122.84\left(\mathrm{q}, J_{\mathrm{C}-\mathrm{F}}=272.5\right.$ $\left.\mathrm{Hz}, \mathrm{CF}_{3}\right), 127.02\left(\mathrm{q}, J_{\mathrm{C}-\mathrm{F}}=5.8 \mathrm{~Hz}\right), 127.35,130.84(\mathrm{~d}$, $\left.J_{\mathrm{C}-\mathrm{F}}=30.8 \mathrm{~Hz}\right), 132.80,139.41,172.59,179.69$. HRMS (ESI): calcd for $\mathrm{C}_{13} \mathrm{H}_{13} \mathrm{~N}_{2} \mathrm{O}_{2} \mathrm{BrF}_{3}\left([\mathrm{M}+\mathrm{H}]^{+}\right)$ 365.0107, found 365.0111. Desmethyl-IGSK1482160: $\mathrm{Mp}$ 195-196 ${ }^{\circ} \mathrm{C} .{ }^{1} \mathrm{H}$ NMR (acetone-d ${ }_{6}$ ): $\delta$ 2.13-2.19 (m, 2H, $\left.\mathrm{CH}_{2}\right), 2.20-2.32(\mathrm{~m}, 1 \mathrm{H}, \mathrm{CH})$, 2.44-2.51 (m, 1H, CH), $4.24(\mathrm{dd}, J=3.0,5.0 \mathrm{~Hz}, 1 \mathrm{H}$, $\mathrm{CH})$, 4.50-4.60 (m, 2H, $\left.\mathrm{CH}_{2}\right), 7.07$ (br s, $\left.1 \mathrm{H}, \mathrm{NH}\right)$, $7.54(\mathrm{t}, J=7.5 \mathrm{~Hz}, 1 \mathrm{H}, \mathrm{Ph}-\mathrm{H}), 7.61(\mathrm{~d}, J=7.5 \mathrm{~Hz}, 1 \mathrm{H}$, $\mathrm{Ph}-\mathrm{H}), 7.64$ (d, J = 7.5 Hz, 1H, Ph-H), 7.96 (br s, 1H, $\mathrm{NH}) .{ }^{13} \mathrm{C} \mathrm{NMR}\left(\mathrm{CDCl}_{3}+\mathrm{CD}_{3} \mathrm{OD}\right): \delta 25.33,29.16$, $49.30,56.70,95.89,122.78\left(\mathrm{q}, J_{\mathrm{C}-\mathrm{F}}=272.1 \mathrm{~Hz}, \mathrm{CF}_{3}\right)$, $126.63\left(\mathrm{q}, J_{\mathrm{C}-\mathrm{F}}=5.8 \mathrm{~Hz}\right), 128.09,131.61,134.40(\mathrm{~d}$, $\left.J_{\mathrm{C}-\mathrm{F}}=30.0 \mathrm{~Hz}\right), 142.58,172.63,179.66$. HRMS (ESI): calcd for $\mathrm{C}_{13} \mathrm{H}_{13} \mathrm{~N}_{2} \mathrm{O}_{2} \mathrm{IF}_{3}\left([\mathrm{M}+\mathrm{H}]^{+}\right)$412.9968, found 412.9970 .

(c). General radiosynthetic method for $\left[{ }^{11} \mathrm{C}\right] \mathrm{F}$ GSK1482160

(trifluoromethyl)benzyl)-1-[ ${ }^{11}$ C]methyl-5-

oxopyrrolidine-2-carboxamide), $\left[{ }^{11} \mathrm{C}\right] \mathrm{Br}$-GSK1482160 ((S)-N-(3-bromo-4-(trifluoromethyl)benzyl)-1-

$\left[{ }^{11}\right.$ C]methyl-5-oxopyrrolidine-2-carboxamide), and $\left.{ }^{11} \mathrm{C}\right] I-G S K 1482160 \quad((S)-N-(3-i o d o-4-$ (trifluoromethyl)benzyl)-1-[ $\left.{ }^{11} \mathrm{C}\right]$ methyl-5-

oxopyrrolidine-2-carboxamide): $\quad\left[{ }^{11} \mathrm{C} \mathrm{CO}_{2} \quad\right.$ was produced by the ${ }^{14} \mathrm{~N}(\mathrm{p}, \alpha){ }^{11} \mathrm{C}$ nuclear reaction in the small volume $\left(9.5 \mathrm{~cm}^{3}\right)$ aluminum gas target provided with the Siemens RDS-111 Eclipse cyclotron. The target gas consisted of $1 \%$ oxygen in nitrogen purchased as a specialty gas from Praxair, Indianapolis, IN. Typical irradiations used for the development were $55 \mu \mathrm{A}$ beam current and 30 min on target. The production run produced approximately $45.5 \mathrm{GBq}$ of $\left[{ }^{11} \mathrm{C}\right] \mathrm{CO}_{2}$ at EOB. In a small reaction vial $(5 \mathrm{~mL})$, the desmethylated precursor 4 (0.3-0.5 mg) was dissolved in $\mathrm{CH}_{3} \mathrm{CN}(500 \mu \mathrm{L})$. To this solution was added $\mathrm{NaOH}-\mathrm{Na}_{2} \mathrm{CO}_{3}$ (solid, w/w 1:2, $1 \mathrm{mg}$ ). No carrier-added (high molar activity) $\left[{ }^{11} \mathrm{C}\right] \mathrm{CH}_{3} \mathrm{OTf}$ that was produced by the gas-phase production method ${ }^{19}$ from $\left[{ }^{11} \mathrm{C}\right] \mathrm{CO}_{2}$ through $\left[{ }^{11} \mathrm{C}\right] \mathrm{CH}_{4}$ and $\left[{ }^{11} \mathrm{C}_{\mathrm{CH}} \mathrm{Cr}\right.$ with silver triflate (AgOTf) column was passed into the reaction vial at $\mathrm{RT}$, until radioactivity reached a maximum ( $\sim 2 \mathrm{~min})$, and then the reaction vial was isolated and heated at $80{ }^{\circ} \mathrm{C}$ for $3 \mathrm{~min}$. The contents of the reaction vial were diluted with $\mathrm{NaHCO}_{3}$ solution $(0.1 \mathrm{M}, 1 \mathrm{~mL})$, and injected onto the semi-preparative RP HPLC column with $3 \mathrm{~mL}$ injection loop for purification. The product fraction was collected in a recovery vial containing $30 \mathrm{~mL}$ water. The diluted tracer solution was then passed through a C-18 SepPak Plus cartridge, and washed with water $(5 \mathrm{~mL} \times 4)$. The cartridge was eluted with $\mathrm{EtOH}(1 \mathrm{~mL} \times 2)$, followed by $10 \mathrm{~mL}$ saline, to release $\left[{ }^{11} \mathbf{C}\right] \mathbf{F}$ GSK1482160, $\left.{ }^{11} \mathrm{C}\right]$ Br-GSK1482160, or $\left.{ }^{[11} \mathrm{C}\right] \mathrm{I}-$ GSK1482160. The eluted product was then sterilefiltered through a sterile vented Millex-FG $0.2 \mu \mathrm{m}$ filter, and collected into a sterile vial. Total radioactivity (4.6-8.2 GBq) was assayed and total volume (10-11 mL) was noted for tracer dose dispensing. The overall synthesis, purification and formulation time was $\sim 40$ min from EOB. Retention times in the analytical RP-HPLC system were: $t_{R}$ desmethyl-F-GSK1482160 $=4.38 \mathrm{~min}, \mathrm{t}_{\mathrm{R}} \mathrm{F}-$ GSK1482160 $=5.55 \mathrm{~min}, \mathrm{t}_{\mathrm{R}}\left[{ }^{11} \mathrm{C}\right] \mathrm{F}-\mathrm{GSK} 1482160=$ $5.61 \mathrm{~min} ; \mathrm{t}_{\mathrm{R}}$ desmethyl-Br-GSK1482160 = $5.75 \mathrm{~min}$, $\mathrm{t}_{\mathrm{R}} \quad \mathrm{Br}-\mathrm{GSK} 1482160=7.45 \mathrm{~min}, \mathrm{t}_{\mathrm{R}}\left[{ }^{11} \mathrm{C}\right] \mathrm{Br}-$ GSK1482160 = $7.52 \mathrm{~min} ;$ and $t_{R}$ desmethyl-IGSK1482160 $=6.50 \mathrm{~min}, \mathrm{t}_{\mathrm{R}} \mathrm{I}-\mathrm{GSK} 1482160=8.55$ $\min , t_{R}\left[{ }^{11} \mathrm{C}\right] \mathrm{I}-\mathrm{GSK} 1482160=8.63 \mathrm{~min}$. Retention times in the semi-preparative RP-HPLC system were: $t_{R}$ desmethyl-F-GSK1482160 $=7.25 \mathrm{~min}, t_{R} \quad F-$ GSK1482160 $=9.00 \mathrm{~min}, \mathrm{t}_{\mathrm{R}}\left[{ }^{11} \mathrm{C}\right] \mathrm{F}-\mathrm{GSK} 1482160=$ $9.08 \mathrm{~min} ; \mathrm{t}_{\mathrm{R}}$ desmethyl-Br-GSK1482160 = $9.21 \mathrm{~min}$, $\mathrm{t}_{\mathrm{R}} \operatorname{Br}-\mathrm{GSK} 1482160=12.76 \mathrm{~min}, \mathrm{t}_{\mathrm{R}}\left[{ }^{11} \mathrm{C}\right] \mathrm{Br}-$ GSK1482160 = $12.82 \mathrm{~min}$; and $t_{R}$ desmethyl-IGSK1482160 = $9.17 \mathrm{~min}, \mathrm{t}_{\mathrm{R}} \mathrm{I}-\mathrm{GSK} 1482160=12.80$ $\min , \quad t_{R} \quad\left[{ }^{11} \mathrm{C}\right] \mathrm{I}-\mathrm{GSK} 1482160=12.93 \mathrm{~min}$. The radiochemical yield was $40-50 \%$ decay corrected to EOB, based on $\left[{ }^{11} \mathrm{C}\right] \mathrm{CO}_{2}$.

(d). Cell culture and membrane preparation: HEK293 cells expressing human recombinant $\mathrm{P} 2 \mathrm{X} 7$ receptor (hP2X7R) were obtained from B'SYS GmbH and cultured according to the supplier's procedure. Cells were grown to $80 \%$ confluency and then rinsed with phosphate-buffered saline (PBS), detached with trypsin, and harvested. Cell pellets were obtained by centrifugation at $200 \mathrm{~g}$ for $5 \mathrm{~min}$ at $4{ }^{\circ} \mathrm{C}$. Collected cell pellets were frozen at $-80{ }^{\circ} \mathrm{C}$ until membrane preparation. For the membrane preparation, pellets from $10 \mathrm{~T} 225$ flasks were homogenized in $50 \mathrm{mM}$ Tris- $\mathrm{HCl}, 5 \mathrm{mM}$ ethylenediaminetetraacetic acid (EDTA), and $140 \mathrm{mM} \mathrm{NaCl}$ at $\mathrm{pH} 7.4$ and $4{ }^{\circ} \mathrm{C}$. The homogenate was then centrifuged at 48,000 $\mathrm{g}$ for 20 min at $4{ }^{\circ} \mathrm{C}$, gently rinsed with deionized water, and then resuspended in $50 \mathrm{mM}$ Tris- $\mathrm{HCl}$ at $\mathrm{pH} 7.4$ and 4 ${ }^{\circ} \mathrm{C}$. This homogenate was then centrifuged as before, with the resulting pellet being homogenized in $50 \mathrm{mM}$ Tris- $\mathrm{HCl}$ at $\mathrm{pH}$ 7.4. Total protein concentration was determined via the Bradford protein assay (Bio-Rad). 
Aliquots were stored in cryovials at $-80{ }^{\circ} \mathrm{C}$ until the day of assay.

(e). $\left[{ }^{11}\right.$ C]GSK1482160 standards: For each experiment, the highest concentration of radioactivity used was diluted twice in assay buffer, followed by eleven 2-fold dilutions. Twenty microliters of each dilution were then spotted onto a GF/B UniFilter-96 plate (Perkin-Elmer) and allowed to air-dry until the end of the experiment. An additional $20 \mu \mathrm{L}$ of each dilution were added to a scintillation vial containing 7 $\mathrm{mL}$ of Optiphase Hisafe 3 (Perkin-Elmer) and counted on an LS6000 scintillation counter (Beckman). Aliquots of the working concentrations of radioactivity used on each day were counted in the same manner.

(f). Radioligand competitive binding assay: For competitive binding assays, cell membrane preparation $(0.054 \mathrm{mg}$ of protein $/ \mathrm{mL}$ of assay medium) was incubated with 11 compound concentrations over a six log unit range, with 5 $\mathrm{nM}\left[{ }^{11} \mathrm{C}\right] \mathrm{GSK} 1482160$ in assay buffer $(50 \mathrm{mM}$ Tris-

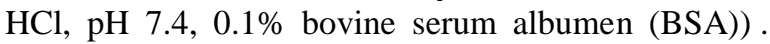
Triplicate determinations were done at each concentration of test compound. GSK1482160 was used to determine non-specific binding. Assays were incubated at $22{ }^{\circ} \mathrm{C}$ for $30 \mathrm{~min}$. For termination of the binding reaction, the samples were filtered onto GF/B UniFilter plates that had been presoaked in $0.5 \%$ polyethyleneimine for $30 \mathrm{~min}$ using a UniFilter-96 cell harvester. The plates were washed 5 times with icecold saline, dried under a vacuum, and exposed to a TR2025 phosphor screen for 20-60 min. Phosphor screens were then read on a Typhoon FLA-7000IP (GE Healthcare) along with $\left[{ }^{11} \mathrm{C}\right]$-calibration standards. CPMs (counts per minute) were determined by calibrating the image to the CPMs in the calibration standards via MCID analysis Software. Data was analyzed with Prism 7.00 (GraphPad Software Inc., La Jolla, California, USA) to determine $\mathrm{K}_{\mathrm{i}}$ and $\mathrm{IC}_{50}$ values. 


\section{Synthesis and in vitro biological evaluation of new} P2X7R radioligands $\left[{ }^{11} \mathrm{C}\right]$ halo-GSK1482160

\section{analogs}

Mingzhang Gao, Min Wang, Jill A. Meyer, Paul R.

Territo, Gary D. Hutchins, Hamideh Zarrinmayeh, Qi-

Huang Zheng*

Department of Radiology and Imaging Sciences, Indiana University School of Medicine, 1345 West $16^{\text {th }}$ Street,

Room 202, Indianapolis, IN 46202, USA<smiles>CN1C(=O)CCC1C(=O)NCc1cccc(C(F)(F)F)c1Cl</smiles>

$\left[{ }^{11} \mathrm{C}\right] \mathrm{GSK} 1482160$

$\mathrm{K}_{\mathrm{i}}=3.1 \pm 0.3 \mathrm{nM}$

$\mathrm{IC}_{50}=8.9 \pm 1.0 \mathrm{nM}$

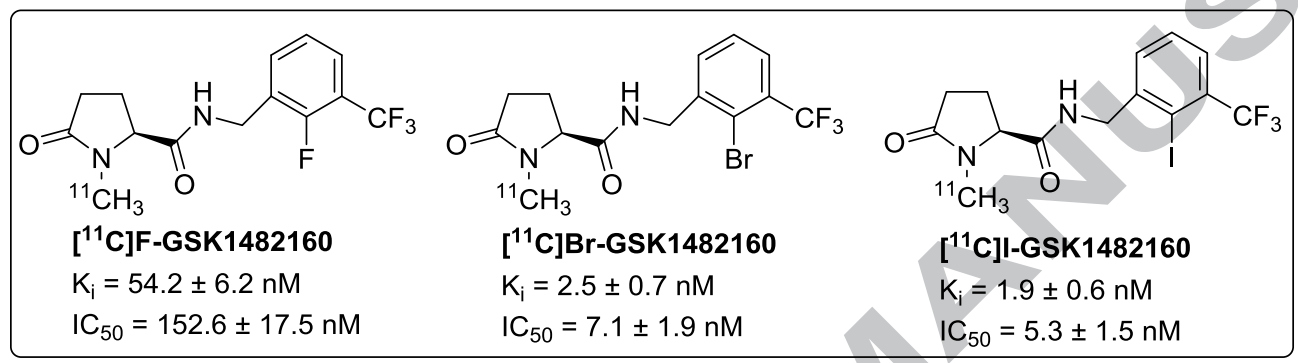

